6

7

\title{
Clean energy from plastic: production of hydroprocessed waste polypropylene pyrolysis oil utilizing Ni-Mo/Laponite catalyst
}

\author{
V.L. Mangesh ${ }^{\mathrm{a}, \mathrm{b},{ }^{*}}$, Tamizhdurai Perumal ${ }^{\mathrm{c}}$, Sivasanker Subramanian ${ }^{\mathrm{d}}$,
}

S. Padmanabhan ${ }^{\mathrm{e}}$

\section{${ }^{a}$ Sathyabama Institute of Science and Technology, Jeppiar Nagar, Chennai-600119, India}

${ }^{b}$ Department of Marine Engineering, Coimbatore Marine College, Coimbatore-641035, India

${ }^{c}$ Environmental and Water Resources Engineering Division, Department of Civil

Engineering, Indian Institute of Technology Madras, Chennai - 600036

${ }^{d}$ National Centre for Catalysis Research, Indian Institute of Technology Madras, Chennai600036

${ }^{e}$ Department of Automobile Engineering, Vel Tech Rangarajan Dr Sagunthala R\&D Institute of Science and Technology, Avadi, Chennai-600062, India

*Corresponding author: V.L.Mangesh

8 Email: vlmangesh@cmcmarine.in

29 ORCID ID: 0000-0003-0996-9822

T: +917299330012 
33 Table of Contents

34

1 Experimental

1.1 Pyrolysis equipment layout- Figure S1(a) and diesel engine layout- Figure 3

S1 (b)

1.2 Diesel engine specifications-Table S1

2 Results and Discussion

2.1 GCMS

2.1.1 GC graph of PPO- Figure S2

2.1.2 GC graph of HPPO-B- Figure S3

2.1.3 GC graph of diesel-Figure $\mathrm{S} 4$

2.1.4 Mass spectrometry of PPO-Table S2

2.1.5 Mass spectrometry of HPPO-B-Table S3

2.1.6 Mass Spectrometry of diesel-Table S4

2.2 Combustion modeling for plastic pyrolysis oil 

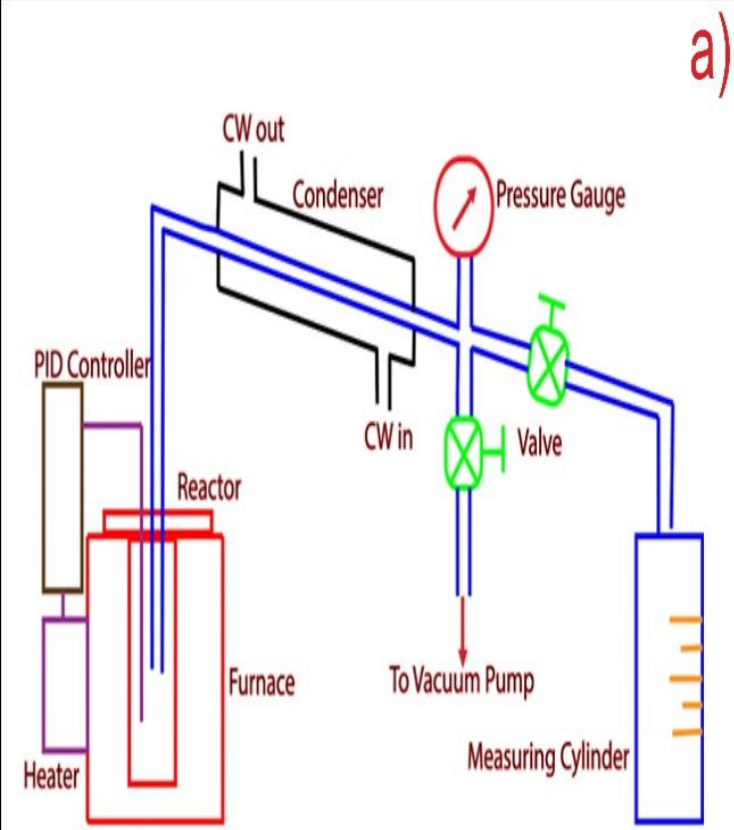

a)
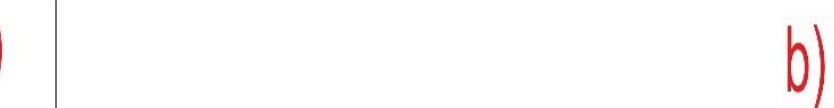

Fig. S1 (a) Pyrolysis Equipment and (b) Engine Layout

57

\subsection{Diesel engine specifications}

Table S1. Engine Specifications

\begin{tabular}{ll}
\hline Engine Brand & Eicher E483 \\
\hline Diesel Engine Type & 4 cylinder in-line T/C, DI \\
Compression ratio & $17.5: 1$ \\
Displacement & $3298 \mathrm{~cm}^{3}$ \\
Max. power & $70 \mathrm{~kW}$ \\
Turbocharger & Boost pressure \\
Injector: hole_dia & 5 _ $0.209 \mathrm{~mm}$ \\
Injection timing & $12{ }^{\circ} \mathrm{CA} \mathrm{btdc}$ \\
Nozzle opening pr & $23 \mathrm{MPa}$ \\
Bore $\times$ Stroke & $100 \mathrm{~mm} \times 105 \mathrm{~mm}$ \\
\hline
\end{tabular}

60 


\subsubsection{GC of PPO}

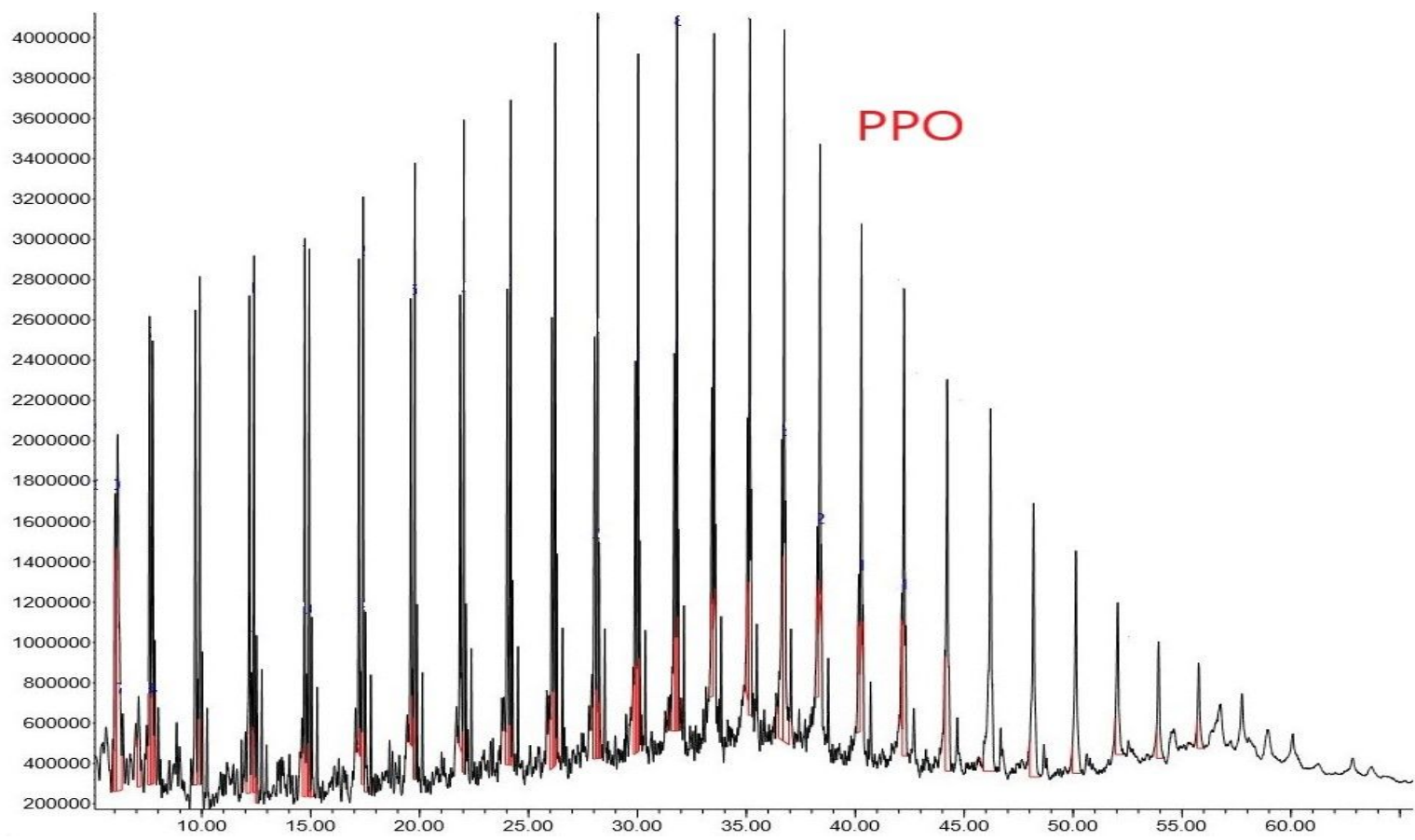

65 Fig. S2 GC graph of PPO

66

67

2.1.2 GC of HPPO-B

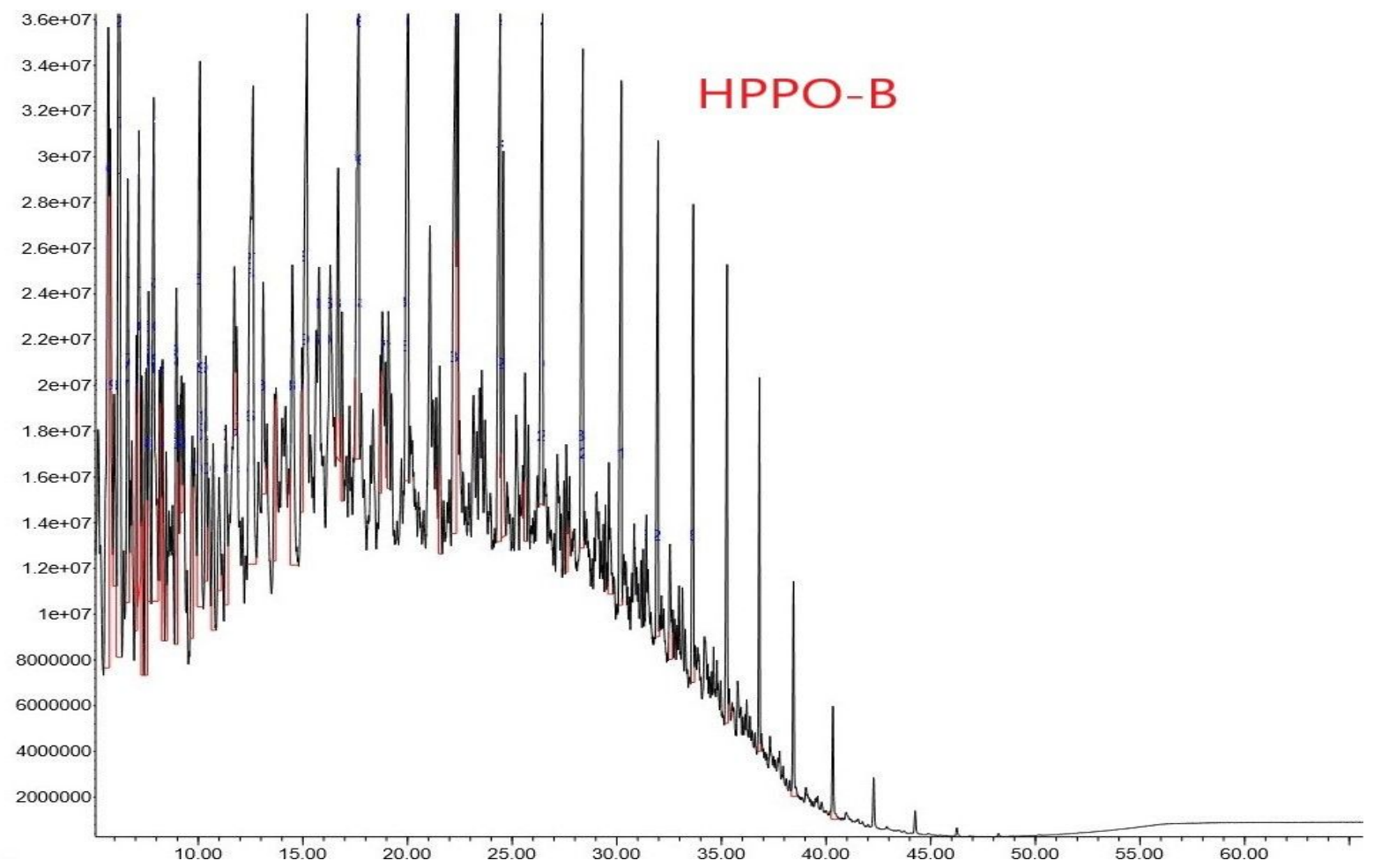

68

Fig. S3 GC graph of HPPO-B 


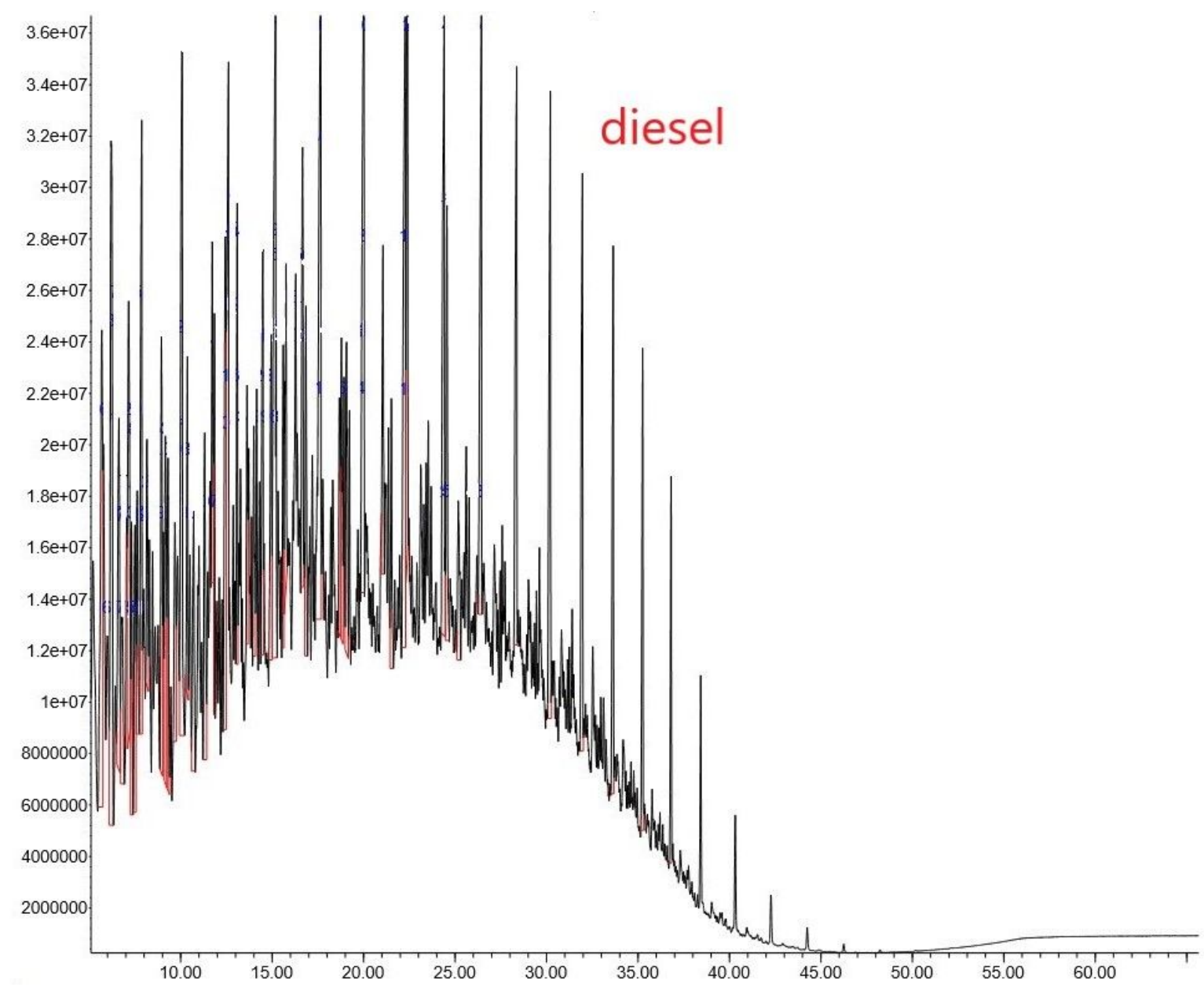

72 Fig. S4 GC graph of diesel

\subsubsection{Table S2. GCMS of PPO}

\begin{tabular}{llll}
\hline RT time & COMPOUND & FORMULA & \%AREA \\
\hline 6.036 & 1-Decene & $\mathrm{C} 10 \mathrm{H} 20$ & 1.81 \\
6.139 & Decane & $\mathrm{C} 10 \mathrm{H} 22$ & 3.02 \\
7.602 & 1-Undecene & $\mathrm{C} 11 \mathrm{H} 22$ & 2.35 \\
7.743 & Undecane & $\mathrm{C} 11 \mathrm{H} 24$ & 2.13 \\
9.706 & 1-Dodecene & $\mathrm{C} 12 \mathrm{H} 24$ & 2.13 \\
9.905 & Dodecane & $\mathrm{C} 12 \mathrm{H} 26$ & 1.76 \\
12.182 & 1-Tridecene & $\mathrm{C} 13 \mathrm{H} 26$ & 2.25 \\
12.401 & Tridecane & $\mathrm{C} 13 \mathrm{H} 28$ & 1.92 \\
12.509 & 3-Tetradecene,(E)- & $\mathrm{C} 14 \mathrm{H} 28$ & 0.7
\end{tabular}




\begin{tabular}{|c|c|c|c|}
\hline 14.729 & 2-Tetradecene,(E)- & $\mathrm{C} 14 \mathrm{H} 28$ & 2.14 \\
\hline 14.934 & Tetradecane & $\mathrm{C} 14 \mathrm{H} 30$ & 1.96 \\
\hline 15.043 & 3-Tetradecene,(Z)- & $\mathrm{C} 14 \mathrm{H} 28$ & 0.6 \\
\hline 17.212 & 1-Pentadecene & $\mathrm{C} 15 \mathrm{H} 30$ & 1.73 \\
\hline 17.411 & Pentadecane & $\mathrm{C} 15 \mathrm{H} 32$ & 2.13 \\
\hline 17.507 & 2-Tetradecene,(E)- & $\mathrm{C} 14 \mathrm{H} 28$ & 0.66 \\
\hline 19.784 & Hexadecane & $\mathrm{C} 16 \mathrm{H} 34$ & 2.28 \\
\hline 21.856 & 1-Heptadecene & $\mathrm{C} 17 \mathrm{H} 34$ & 1.92 \\
\hline 22.036 & Heptadecane & $\mathrm{C} 17 \mathrm{H} 36$ & 2.44 \\
\hline 24.018 & 1-Nonadecene & $\mathrm{C} 19 \mathrm{H} 38$ & 2.26 \\
\hline 24.185 & Octadecane & $\mathrm{C} 18 \mathrm{H} 38$ & 2.55 \\
\hline 26.071 & 1-Nonadecene & $\mathrm{C} 19 \mathrm{H} 38$ & 2.28 \\
\hline 26.225 & Nonadecane & $\mathrm{C} 19 \mathrm{H} 40$ & 2.75 \\
\hline 28.028 & 1-Octadecene & $\mathrm{C} 18 \mathrm{H} 36$ & 2.23 \\
\hline 28.175 & Heptadecane & $\mathrm{C} 17 \mathrm{H} 36$ & 2.89 \\
\hline 28.241 & 1-Nonadecene & $\mathrm{C} 19 \mathrm{H} 38$ & 0.64 \\
\hline 29.908 & Octadecene & $\mathrm{C} 18 \mathrm{H} 36$ & 2.06 \\
\hline 30.036 & Henicosane & $\mathrm{C} 21 \mathrm{H} 44$ & 3.01 \\
\hline 31.691 & 9-Nonadecene & $\mathrm{C} 19 \mathrm{H} 38$ & 2.1 \\
\hline 31.819 & Octadecane & $\mathrm{C} 18 \mathrm{H} 38$ & 3 \\
\hline 33.411 & Octadecene & $\mathrm{C} 18 \mathrm{H} 36$ & 1.52 \\
\hline 33.526 & Octadecane & $\mathrm{C} 18 \mathrm{H} 38$ & 2.19 \\
\hline 35.059 & 9-Nonadecene & $\mathrm{C} 19 \mathrm{H} 38$ & 1.33 \\
\hline 35.168 & Tetracosane & $\mathrm{C} 24 \mathrm{H} 50$ & 3.61 \\
\hline 36.637 & 9-Nonadecene & $\mathrm{C} 19 \mathrm{H} 38$ & 2.06 \\
\hline 36.746 & Henicosane & $\mathrm{C} 21 \mathrm{H} 44$ & 4.06 \\
\hline 38.254 & Octadecene & $\mathrm{C} 18 \mathrm{H} 36$ & 0.94 \\
\hline 38.382 & Pentacosane & $\mathrm{C} 25 \mathrm{H} 52$ & 1.94 \\
\hline 40.159 & Eicosene & $\mathrm{C} 2 \mathrm{OH} 40$ & 0.92 \\
\hline 40.288 & Pentacosane & $\mathrm{C} 25 \mathrm{H} 52$ & 1.9 \\
\hline 42.244 & Tetracosane & $\mathrm{C} 24 \mathrm{H} 50$ & 3.14 \\
\hline
\end{tabular}




$\begin{array}{llll}44.221 & \text { Pentacosane } & \mathrm{C} 25 \mathrm{H} 52 & 2.94 \\ 46.209 & \text { Heneicosane } & \mathrm{C} 21 \mathrm{H} 44 & 3.37 \\ 48.185 & \text { Heneicosane } & \mathrm{C} 21 \mathrm{H} 44 & 2.48 \\ 50.129 & \text { Tetracosane } & \mathrm{C} 24 \mathrm{H} 50 & 1.92 \\ 52.047 & \text { Tetracosane } & \mathrm{C} 24 \mathrm{H} 50 & 1.34 \\ 53.926 & \text { Eicosane } & \mathrm{C} 20 \mathrm{H} 42 & 0.98 \\ 55.761 & \text { Eicosane } & \mathrm{C} 2 \mathrm{OH} 42 & 0.66\end{array}$

2.1.5 Table S3. GCMS of HPPO-B

\begin{tabular}{|c|c|c|c|}
\hline RT time & Compound & Chemical Formula & $\%$ Area \\
\hline 5.703 & Benzene, 1-ethyl-3-methyl- & $\mathrm{C} 9 \mathrm{H} 12$ & 5.45 \\
\hline 5.979 & Benzene, 1-ethyl-2-methyl- & $\mathrm{C} 9 \mathrm{H} 12$ & 1.05 \\
\hline 6.21 & Benzene, 1,2,3-trimethyl- & $\mathrm{C} 9 \mathrm{H} 12$ & 6.21 \\
\hline 6.633 & Benzene, 1,2,3-trimethyl- & $\mathrm{C} 9 \mathrm{H} 12$ & 2.38 \\
\hline 7.051 & Benzene, 1-methyl-3-propyl & $\mathrm{C} 10 \mathrm{H} 14$ & 1.16 \\
\hline 7.165 & Benzene, 2-ethyl-1,4-dimethyl- & $\mathrm{C} 10 \mathrm{H} 14$ & 2.94 \\
\hline 7.313 & Decane, 3-methyl- & $\mathrm{C} 11 \mathrm{H} 24$ & 1.2 \\
\hline 7.499 & Benzene, 1-ethyl-2,4-dimethyl- & $\mathrm{C} 10 \mathrm{H} 14$ & 1.79 \\
\hline 7.627 & Benzene, 4-ethyl-1,2-dimethyl- & $\mathrm{C} 10 \mathrm{H} 14$ & 1.6 \\
\hline 7.871 & Undecane & $\mathrm{C} 11 \mathrm{H} 24$ & 3.73 \\
\hline 8.161 & Naphthalene, decahydro-2-methyl & $\mathrm{C} 11 \mathrm{H} 20$ & 0.72 \\
\hline 8.294 & Benzene, 1,2,3,4-tetramethyl- & $\mathrm{C} 10 \mathrm{H} 14$ & 1.21 \\
\hline 8.468 & Naphthalene, decahydro-2-methyl & $\mathrm{C} 11 \mathrm{H} 20$ & 0.64 \\
\hline 8.955 & Benzene, 1,2-diethyl- & $\mathrm{C} 10 \mathrm{H} 14$ & 2.03 \\
\hline 9.199 & Napthalene, 1,2,3,4-tetrahydro- & $\mathrm{C} 13 \mathrm{H} 18$ & 0.82 \\
\hline 9.719 & Naphthalene & $\mathrm{C} 10 \mathrm{H} 8$ & 1.21 \\
\hline 10.084 & Dodecane & $\mathrm{C} 12 \mathrm{H} 26$ & 4.29 \\
\hline 10.367 & Undecane, 2,6-dimethyl- & $\mathrm{C} 13 \mathrm{H} 28$ & 1.12 \\
\hline 10.707 & Benzene, (2-chloro-2-butenyl)- & $\mathrm{C} 11 \mathrm{H} 14$ & 1.18 \\
\hline
\end{tabular}




\begin{tabular}{|c|c|c|c|}
\hline 11.727 & Naphthalene, 1,2,3,4-tetrahydro-5-methyl- & $\mathrm{C} 11 \mathrm{H} 14$ & 0.76 \\
\hline 12.625 & Tridecane & $\mathrm{C} 13 \mathrm{H} 28$ & 5.99 \\
\hline 13.106 & Naphthalene, 1,2,3,4-tetrahydro-1, 4-dimethyl- & $\mathrm{C} 12 \mathrm{H} 16$ & 1.17 \\
\hline 13.638 & Naphthalene, 1,2,3,4-tetrahydro-1, 4-dimethyl- & $\mathrm{C} 12 \mathrm{H} 16$ & 0.9 \\
\hline 14.492 & Dodecane, 2,6,10-trimethyl- & $\mathrm{C} 15 \mathrm{H} 32$ & 2.66 \\
\hline 14.961 & Naphthalene, 1,2,3,4-tetrahydro-1, 5-dimethyl & $\mathrm{C} 12 \mathrm{H} 16$ & 0.89 \\
\hline 16.686 & Pentacosane & $\mathrm{C} 25 \mathrm{H} 52$ & 1.83 \\
\hline 16.865 & Tetradecane, 3-methyl- & $\mathrm{C} 15 \mathrm{H} 32$ & 0.84 \\
\hline 17.681 & Pentadecane & $\mathrm{C} 15 \mathrm{H} 32$ & 3.76 \\
\hline 18.713 & Naphthalene, 1,6,7-trimethyl- & $\mathrm{C} 13 \mathrm{H} 14$ & 0.63 \\
\hline 19.085 & Dodecane & $\mathrm{C} 12 \mathrm{H} 26$ & 0.97 \\
\hline 20.035 & Hexadecane & $\mathrm{C} 16 \mathrm{H} 34$ & 3.9 \\
\hline 21.536 & Hexadecane, 3-methyl & $\mathrm{C} 17 \mathrm{H} 36$ & 0.85 \\
\hline 22.306 & Heptadecane & $\mathrm{C} 17 \mathrm{H} 36$ & 4.74 \\
\hline 24.429 & Octadecane & $\mathrm{C} 18 \mathrm{H} 38$ & 3.97 \\
\hline 24.583 & Hexadecane, 2,6,10,14-tetramethyl- & $\mathrm{C} 2 \mathrm{OH} 42$ & 1.97 \\
\hline 25.616 & Octadecane, 2-methyl- & $\mathrm{C} 19 \mathrm{H} 40$ & 0.79 \\
\hline 26.456 & Heptadecane & $\mathrm{C} 17 \mathrm{H} 36$ & 3.17 \\
\hline 27.585 & Heptadecane, 3-methyl & $\mathrm{C} 18 \mathrm{H} 38$ & 0.49 \\
\hline 28.381 & Heptadecane & $\mathrm{C} 17 \mathrm{H} 36$ & 3.04 \\
\hline 30.216 & Heneicosane & $\mathrm{C} 21 \mathrm{H} 44$ & 2.99 \\
\hline 31.981 & Heptadecane, 3-methyl & $\mathrm{C} 18 \mathrm{H} 38$ & 2.61 \\
\hline 32.538 & Heptadecane, 3-methyl & $\mathrm{C} 18 \mathrm{H} 38$ & 0.69 \\
\hline 33.661 & Heptadecane, 9-octyl- & $\mathrm{C} 25 \mathrm{H} 52$ & 2.3 \\
\hline 35.271 & Tetracosane & $\mathrm{C} 24 \mathrm{H} 50$ & 1.91 \\
\hline 36.817 & Eicosane & $\mathrm{C} 2 \mathrm{OH} 42$ & 1.3 \\
\hline 38.446 & Eicosane & $\mathrm{C} 2 \mathrm{OH} 42$ & 0.93 \\
\hline 40.326 & Tetracosane & $\mathrm{C} 24 \mathrm{H} 50$ & 0.53 \\
\hline
\end{tabular}




\begin{tabular}{|c|c|c|c|}
\hline RT time & Compound & Chemical Formula & $\%$ Area \\
\hline 5.683 & Benzene, 1-ethyl-2-methyl- & $\mathrm{C} 9 \mathrm{H} 12$ & 3.46 \\
\hline 6.191 & Benzene, 1,2,3-trimethyl- & $\mathrm{C} 9 \mathrm{H} 12$ & 4.62 \\
\hline 6.621 & Benzene, 1,2,4-trimethyl- & $\mathrm{C} 9 \mathrm{H} 12$ & 1.99 \\
\hline 6.755 & Cyclohexane, butyl- & $\mathrm{C} 10 \mathrm{H} 20$ & 1.13 \\
\hline 7.153 & Benzene, 2-ethyl-1,4-dimethyl- & $\mathrm{C} 10 \mathrm{H} 14$ & 2.47 \\
\hline 7.307 & Decane, 3-methyl- & $\mathrm{C} 11 \mathrm{H} 24$ & 1.03 \\
\hline 7.493 & Benzene, 1-ethyl-2,4-dimethyl- & $\mathrm{C} 10 \mathrm{H} 14$ & 1.36 \\
\hline 7.621 & Benzene, 1-methyl-3-(1-methylethyl-) & $\mathrm{C} 10 \mathrm{H} 14$ & 1.04 \\
\hline 7.865 & Undecane & $\mathrm{C} 11 \mathrm{H} 24$ & 2.64 \\
\hline 8.153 & Naphthalene, decahydro-2-methyl & $\mathrm{C} 11 \mathrm{H} 20$ & 0.99 \\
\hline 8.942 & Benzene, 1,4-diethyl- & $\mathrm{C} 10 \mathrm{H} 14$ & 1.87 \\
\hline 9.161 & Undecane, 2-methyl- & $\mathrm{C} 12 \mathrm{H} 26$ & 1.94 \\
\hline 9.308 & Undecane, 3-methyl- & $\mathrm{C} 12 \mathrm{H} 26$ & 1.32 \\
\hline 9.681 & Decane & $\mathrm{C} 10 \mathrm{H} 22$ & 1.15 \\
\hline 10.072 & Dodecane & $\mathrm{C} 12 \mathrm{H} 26$ & 3.81 \\
\hline 10.367 & Undecane, 2,6-dimethyl- & $\mathrm{C} 13 \mathrm{H} 28$ & 1.07 \\
\hline 10.707 & Benzene, (2-chloro-2-butenyl)- & $\mathrm{C} 10 \mathrm{H} 11 \mathrm{Cl}$ & 1.39 \\
\hline 11.311 & Benzene, (2-methyl-1-butenyl)- & $\mathrm{C} 11 \mathrm{H} 14$ & 1.6 \\
\hline 11.721 & Napthalene, 1,2,3,4-tetrahydro-6-methyl- & $\mathrm{C} 11 \mathrm{H} 14$ & 1.14 \\
\hline 11.842 & Tridecane, 7-methyl- & $\mathrm{C} 14 \mathrm{H} 30$ & 0.96 \\
\hline 12.439 & Napthalene, 2-methyl- & $\mathrm{C} 11 \mathrm{H} 10$ & 2.56 \\
\hline 13.087 & $\begin{array}{l}\text { Naphthalene, 1,2,3,4-tetrahydro-1, 4- } \\
\text { dimethyl- }\end{array}$ & $\mathrm{C} 12 \mathrm{H} 16$ & 1.41 \\
\hline 13.998 & Tridecane, 4-methyl- & $\mathrm{C} 14 \mathrm{H} 30$ & 0.97 \\
\hline 14.492 & Dodecane, 2,6,10-trimethyl- & $\mathrm{C} 15 \mathrm{H} 32$ & 1.87 \\
\hline 14.941 & Naphthalene, 1,2,3,4-tetrahydro-5,7-dimethyl & $\mathrm{C} 12 \mathrm{H} 16$ & 1.51 \\
\hline 15.185 & Tetradecane & $\mathrm{C} 14 \mathrm{H} 30$ & 4.75 \\
\hline 15.602 & Napthalene, 2,7-dimethyl- & $\mathrm{C} 12 \mathrm{H} 12$ & 1.13 \\
\hline 15.756 & Naphthalene, 1,6,7-trimethyl- & $\mathrm{C} 13 \mathrm{H} 14$ & 1.43 \\
\hline
\end{tabular}




\begin{tabular}{llll}
16.661 & Pentacosane & $\mathrm{C} 25 \mathrm{H} 52$ & 1.88 \\
16.841 & Tetradecane, 3-methyl- & $\mathrm{C} 15 \mathrm{H} 32$ & 1.21 \\
17.654 & Pentadecane & $\mathrm{C} 15 \mathrm{H} 32$ & 4.71 \\
18.674 & Naphthalene, 2,3,6-trimethyl- & $\mathrm{C} 13 \mathrm{H} 14$ & 0.97 \\
19.066 & Pentadecane, 2-methyl- & $\mathrm{C} 16 \mathrm{H} 34$ & 1.47 \\
20.015 & Hexadecane & $\mathrm{C} 16 \mathrm{H} 34$ & 3.76 \\
21.061 & Pentadecane, 2,6,10-trimethyl- & $\mathrm{C} 18 \mathrm{H} 38$ & 1.32 \\
21.516 & Hexadecane, 3-methyl- & $\mathrm{C} 17 \mathrm{H} 36$ & 0.94 \\
22.273 & Heptadecane & $\mathrm{C} 17 \mathrm{H} 36$ & 4.18 \\
22.402 & Pentadecane, 2,6,10,14-tetramethyl- & $\mathrm{C} 19 \mathrm{H} 40$ & 2.46 \\
24.403 & Octadecane & $\mathrm{C} 18 \mathrm{H} 38$ & 3.56 \\
24.557 & Hexadecane, 2,6,10,14-tetramethyl- & $\mathrm{C} 2 \mathrm{OH} 42$ & 1.85 \\
26.437 & Heptadecane & $\mathrm{C} 17 \mathrm{H} 36$ & 3.04 \\
28.368 & Heptadecane & $\mathrm{C} 17 \mathrm{H} 36$ & 2.75 \\
30.209 & Heneicosane & $\mathrm{C} 21 \mathrm{H} 44$ & 2.84 \\
31.961 & Heptadecane, 3-methyl & $\mathrm{C} 18 \mathrm{H} 38$ & 2.45 \\
33.641 & Heptadecane & $\mathrm{C} 17 \mathrm{H} 36$ & 2.04 \\
35.252 & Tetracosane & $\mathrm{C} 24 \mathrm{H} 50$ & 1.65 \\
36.811 & Pentacosane & $\mathrm{C} 25 \mathrm{H} 52$ & 1.14 \\
\hline & & & \\
\hline
\end{tabular}

\subsection{Combustion Modeling} PPO comprises alkanes, alkenes, and aromatic compounds. PPO, as a diesel fuel, has been extensively studied in the past. However, the performance of PPO as a diesel engine fuel has not matched that of commercial diesel's. In this model, we study the droplet evaporation and

87 combustion of the vapourized droplets of PPO. The first factor is the presence of alkanes and alkenes of a higher carbon, which influences the evaporation of the droplets. The second factor is the presence of alkene compounds in PPO, which influences the combustion of the vaporized droplets. These factors that affect combustion have been modelled and studied in this paper. 
91 The heat flux which is available for diffusion at the droplet surface can be expressed in the

92 form of the following equation:

$93 \mathrm{q} "=\stackrel{r}{\mathrm{r}} \rho_{\mathrm{f}} \mathrm{QV}$

94 In the above equation, q" is the heat flux $\left(\mathrm{KJ} / \mathrm{m}^{2} . \mathrm{s}\right)$ which is available at the droplet surface

95 droplet to enable vaporization, $\mathrm{r}$ is the droplet regression rate $(\mathrm{m} / \mathrm{s})$, of represents the density

96 of the fuel, and QV is the overall heat of evaporation per $\mathrm{kg}$ of fuel. The schematics of

97 droplet evaporation is shown in Fig. S5 (a). The availability of heat flux q" can be approximately the same for both PPO and diesel, as the heat prior to fuel ignition remains the same. Assuming q" and that $\rho_{\mathrm{f}}$ remains constant, we can deduce the following:

$100 \quad \dot{\mathrm{r}}=\frac{C}{Q V}$

101 In the above equation, $\mathrm{C}=\frac{q^{\prime \prime}}{\rho f}$. As observed in Equation 2, an increase in $\mathrm{QV}$ value will result in a decrease in the regression rate ŕ. A lower regression rate of droplet implies increased time to vaporize the droplet completely, which implies increased ignition delay. With respect to the heat of evaporation, QV is composed of a specific heat and the latent heat of evaporation. The specific heat has been neglected, as its value is negligible when compared to the latent heat of evaporation. Neglecting the specific heat, the equation 2 is presented as below:

$107 \quad \dot{\mathrm{r}}=\frac{C}{\Delta H}$

Fig. S5 (a) shows the latent heat $\Delta \mathrm{H}$ for various carbon numbers of alkanes and alkenes [1-5]. The latent heat of $\mathrm{C}_{30} \mathrm{H}_{62}$ carbon number compound is 3 times higher than the latent heat of the $\mathrm{C}_{10} \mathrm{H}_{22}$ compound. The regression rate decreases, as the $\Delta \mathrm{H}$ increases for compounds with a higher carbon number. It can be deduced from the model that PPO, which possess a fuel of a high carbon number, will produce a higher ignition delay in diesel engines. 
113 The second factor is the presence of alkenes and the influence of these compounds in 114 combustion of vapourized droplets; this factor is modelled using the stoichiometric equation 115 and the bond dissociation energy (BDE) of the compounds.

116 The stoichiometric equation for an evaporated hydrocarbon fuel is expressed as follows:

$117 \mathrm{C} \alpha \mathrm{H} \beta+(\alpha+\beta / 4) \mathrm{O} 2=\alpha \mathrm{CO} 2+\beta \mathrm{H} 2 \mathrm{O}$

118 The factor of nitrogen present in the air is neglected, as the heat of reaction involving nitrogen 119 is negligible. The reactant side of Equation 4 is an endothermic reaction with heat being absorbed to dissociate the bonds to facilitate product creation. The product side of the equation 4 is an exothermic reaction with heat being released from the formation. Equation 4 facilitates the comparison of the BDE between the two fuels viz. alkanes and alkenes. The carbon number $\alpha$ remains the same for compounds of the two fuels with the same carbon number, eg., decane $\left(\mathrm{C}_{10} \mathrm{H}_{22}\right)$ and decene $\left(\mathrm{C}_{10} \mathrm{H}_{20}\right)$. The $\beta$ value changes between an alkane and alkene; for decane, it's $\beta$, and for decene, it is $(\beta-2)$. In the product side of Equation 4 , the amount of exothermic heat released due to bond association for alkanes and alkenes produces minor variation. In the reactant side, the variation in $\mathrm{O}_{2}$ dissociation energy between the two fuels is minor. The significant difference is noted in the endothermic reaction of the hydrocarbon compound $\left(\mathrm{C}_{\alpha} \mathrm{H}_{\beta}\right)$ reactant in Equation 4. The BDE of the reactants of the two fuels is studied as per the following equation:

$\mathrm{C}_{\alpha} \mathrm{H}_{\beta-2}(\mathrm{BDE})=(\beta-2)(\mathrm{C}-\mathrm{H})+(\alpha-1)(\mathrm{C}=\mathrm{C})$

The Equation 5 represents alkane fuel, and Equation 6 represents alkene fuel. The energy of C$\mathrm{H}$ bonds between the two fuels is the same, and the multiples $\beta$ and $(\beta-2)$ produce minor 
variations in $\mathrm{C}-\mathrm{H}$ bonds between the two fuels. The bond energy of $\mathrm{C}-\mathrm{C}$ and $\mathrm{C}=\mathrm{C}$ of the two fuels bring about a large difference in combustion.

The BDE for $\mathrm{C}-\mathrm{C}$ is $364 \mathrm{KJ} / \mathrm{mol}$, whereas it is $614 \mathrm{KJ} / \mathrm{mol}$ for $\mathrm{C}=\mathrm{C}$ bonds. The net heat $(\Delta \mathrm{Q})$ available is the difference between the exothermic reaction of the products and the endothermic heat of the reactants. $\Delta \mathrm{Q}$ of decane, decene, pentadecane, pentadecene, eicosane, and eicosene have been shown in Fig. S5 (b). The $\Delta \mathrm{Q}$ of alkanes is observed to be approximately $50 \%$ higher than alkenes. The high BDE of alkene fuels results in a lower $\Delta \mathrm{Q}$ being obtained from combustion, and this will reflect in lower thermal efficiency. The theoretical models show the unsuitability of PPO as a diesel engine fuel. PPO needs to be upgraded as a diesel fuel through hydroprocessing. Our HPPO-B is an upgraded product, and the diesel engine combustion trials of HPPO-B validate the theoretical findings.
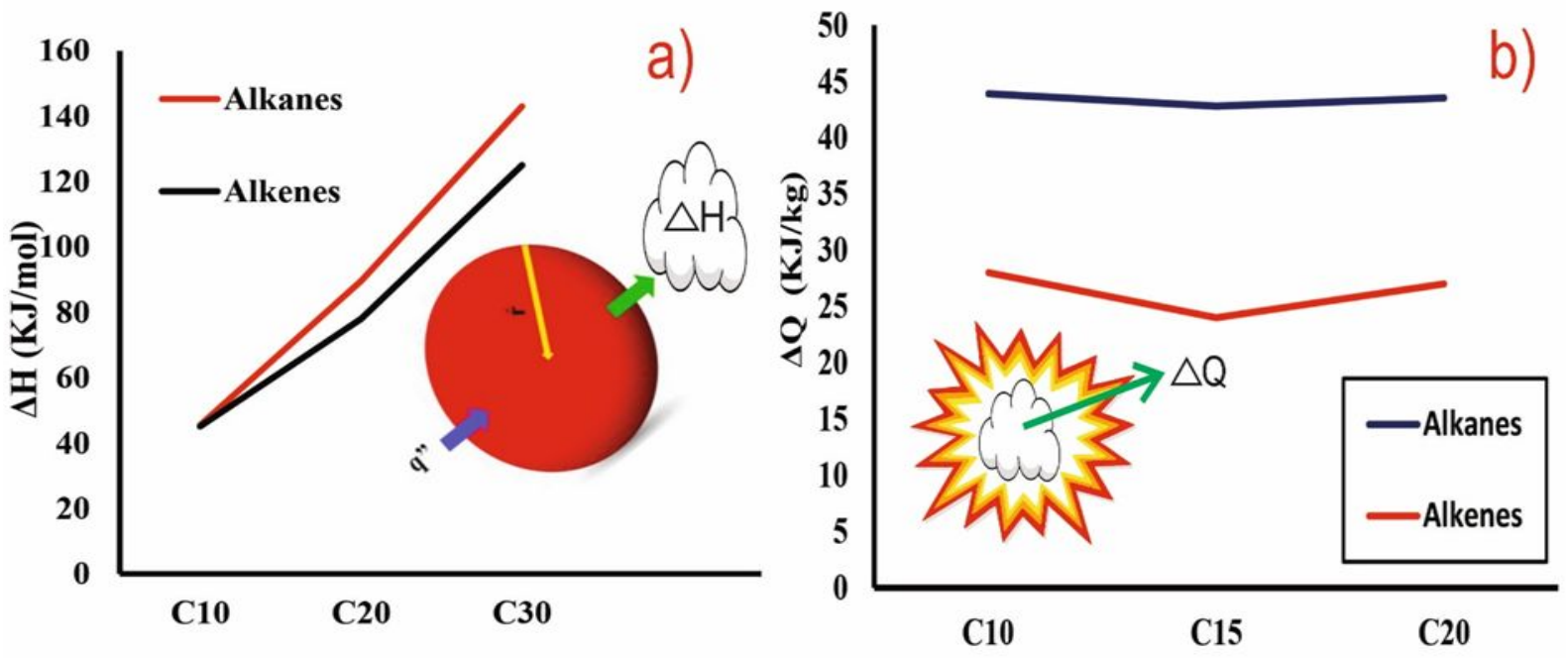

Fig. S5 (a) The variation of latent heat $(\Delta \mathrm{H})$ with carbon number of fuels and (b) The net heat released from combustion $(\Delta Q)$ for alkanes and alkanes.

\section{References}

[1] Williamham, C.B.; Taylor, W.J.; Pignocco, J.M.; Rossini, F.D. Vapor Pressures and 
157 [2] Forziati, A.F.; Camin, D.L.; Rossini, F.D. Density, refractive index, boiling point, and 158 vapor pressure of eight mono olefin (1-alkene), six pentadiene, and two cyclo mono olefin hydrocarbons, J. Res. NBS, 1950, 45, 406-410.

[3] Sasse, K.; Jose, J.; Merlin, J. A static apparatus for measurement of low vapor pressures.

161 Experimental results on high molecular-weight hydrocarbons, Fluid Phase Equilibria, 1998, 42, 287-304.

[4] Dykyj, J.; Svoboda, J.; Wilhoit, R.C.; Frenkel, M.L; Hall, K.R. Vapor Pressure of

164 Chemicals: Part A. Vapor Pressure and Antoine Constants for Hydrocarbons and Sulfur, 165 Selenium, Tellurium and Hydrogen Containing Organic Compounds, Springer, Berlin, $1661999,373$.

167 [5] Piacente, V.; Fontana, D.; Scardala, P.; Enthalpies of Vaporization of a Homologous Series 168 of n-Alkanes Determined from Vapor Pressure Measurements, J. Chem. Eng. Data 1994, $39,231-237$. 